\title{
The Effect of Seaweed (Eucheuma cottonii) Flour Addition on Physicochemical and Sensory Characteristics of an Indonesian-Style Beef Meatball
}

\author{
Aris Sri Widatia ${ }^{\mathrm{a}}$, Djalal Rosyidi ${ }^{\mathrm{b}}$, Lilik Eka Radiati ${ }^{\mathrm{b}}$, ANd Happy Nursyam ${ }^{\mathrm{c}}$ \\ ${ }^{a}$ Post Graduate Program, Faculty of Animal Science, Universitas Brawijaya, Jl. Veteran, Malang 65145, \\ Indonesia \\ ${ }^{\mathrm{b}}$ Faculty of Animal Science, Universitas Brawijaya, Jl. Veteran, Malang 65145, Indonesia \\ ${ }^{\mathrm{c}}$ Faculty of Fisheries and Marine Science, Universitas Brawijaya, Jl. Veteran, Malang 65145, Indonesia \\ * Corresponding author \\ djalal_tht@ub.ac.id \\ TEL.: +62-341-553513
}

Received: 19 November 2019; Published online: 24 February 2021

\begin{abstract}
The objective of this work was to study the effect of seaweed (Eucheuma cottonii) flour addition on physicochemical and sensory characteristics of an Indonesian-style beef meatball. Seaweed flour (SF) was added to meatball batter at $0 \%(\mathrm{CON}), 2.5 \%(\mathrm{SF} 2.5), 5.0 \%$ (SF5) and $7.5 \%$ (SF7.5) in weight/meat weight $(\mathrm{w} / \mathrm{w})$ basis. Proximate composition (moisture, crude protein, crude fat, crude fiber and ash content), $\mathrm{pH}$, cooking loss, hardness, water-holding capacity, instrumental color and sensory properties (color, texture, aroma, taste and overall acceptability) of the boiled meatballs were evaluated. The effect of seaweed flour addition was very significant $(\mathrm{P}<0.01)$ on moisture, crude fat, crude fiber, ash, cooking loss, hardness, water-holding capacity, lightness $\left(\mathrm{L}^{*}\right)$, yellowness $\left(\mathrm{b}^{*}\right)$ and all sensory properties, and was significant $(\mathrm{P}<0.05)$ on crude protein, $\mathrm{pH}$ and the redness $\left(\mathrm{a}^{*}\right)$ of a boiled Indonesian-style beef meatball. The addition of seaweed flour at more than $2.5 \%$ resulted in darker meatballs, with less protein and fat, and a stronger seaweed aroma. The results suggest that seaweed flour could be added at $2.5 \%(\mathrm{w} / \mathrm{w})$ to produce an Indonesian-style beef meatball with enhanced fiber content.
\end{abstract}

Keywords: Eucheuma cottonii; Fiber; Meatball; Seaweed flour

\section{Introduction}

An Indonesian style-meatball or bakso is a boiled-type of meatball and among the most favoured traditional restructured meat products found in the Indonesian market (Purnomo \& Rahardiyan, 2008). The name bakso originated from the word, Hokkien for finely chopped meat mixed with starch and seasonings (Tan, 2002). It has a short shelf life (max. 1 day) when stored at $13^{\circ} \mathrm{C}$ but can be stored frozen in order to extend its shelf life (Rifqie Mariana, Hidayati \& Soeko-

Copyright (C)2021 ISEKI-Food Association (IFA) pitojo, 2019). From the nutritional point of view, the Indonesian-style beef meatball is a source of energy and protein. However, it lacks dietary fiber as it is made from meat, starch (tapioca), egg white and seasonings. Tapioca functions as a filler and egg white is used as a binder (Purnomo, 2012). The high-quality meatballs should meet the national standard set by (Badan Standardisasi Nasional, 1995). The meatballs should contain a maximum of $70 \%$ moisture, $2.0 \%$ fat and $3.0 \%$ ash, and a minimum of $9.0 \%$ protein, and 
have a meaty flavour, umami taste, normal appearance (light brown and light grey) and chewy texture.

The physicochemical and sensory characteristics of Indonesian-style beef meatballs are influenced by the ingredients and methods of processing and packaging (Purnomo, 2012). A higher proportion of meat in the formulation of the meatballs increases the proportion of protein and fat, and reduces the chewiness. In contrast, a lower proportion of meat (replaced by starch) increases chewiness but lowers the protein and fat content. Sodium tripolyphosphate (E451) has been widely used to overcome water-holding capacity and texture issues in restructured meat products (Lee, Hendricks \& Cornforth, 1998). Even though this additive is categorized and generally recognized as safe by the US FDA, it is preferable to use a natural ingredient. To attain the required nutritional value and chewy texture, the natural ingredient added to the meatballs' formula must function as a binder and a filler.

Eucheuma cottonii is an edible seaweed species that is categorized as Rodhopycheae. This seaweed is rich in k-carrageenan which functions as a stabilizer and a water-binder, and strengthens protein gel development in heatinduced emulsion-type food products (MacArtain, Gill, Brooks, Campbell \& Rowland, 2007). The k-carrageenan extracted from red seaweed has been widely used within the meat processing industry as a water-binder (Campo, Kawano, da Silva \& Carvalho, 2009). The kcarrageenan from Eucheuma cottonii has been used in the production of chicken and catfish meatballs to improve water-holding capacity, cooking yield and texture, and increase fiber in those products (Kurniawan, Al-Baarri \& Kusrahayu, 2012; Yakhin, Wijaya \& Santoso, 2015). Hartati and Endang (2011) reported the addition of ground and raw Eucheuma cottonii at 2.5\% of meat weight improved the acceptability of Indonesian-style beef meatballs. However, there is no information regarding the use of Eucheuma cottonii flour in Indonesian-style beef meatball manufacture. Raw seaweed is more susceptible to quality degradation and has a shorter shelf-life than the flour (Guerrero, Campos \& Alzamora, 2002). Therefore, the objective of the present study was to determine the optimal addition level of Eucheuma cottonii flour in the formulation of an Indonesian-style beef meatball.

\section{Materials and Methods}

\subsection{Seaweed flour preparation}

Seaweed (Eucheuma cottonii) flour was made according to a method described by Manuel, Cornelia and Wijaya (2015), with modifications in drying temperature and time. Semi-dried seaweed was purchased from a local market, washed to remove sand, soaked in water for $12 \mathrm{~h}$ and drained for $60 \mathrm{~min}$ at room temperature. Seaweed was cut into $3 \mathrm{~cm}$ lengths, dehydrated at $60^{\circ} \mathrm{C}$ for 24 h (YTK ST-02, Yason General Machinery, Guangdong, China), ground using a food miller (FGD230, Ramesia Mesin Indonesia, Jakarta, Indonesia), sieved through an 80 mesh-sieve, airpacked and stored at room temperature prior to use.

\subsection{Meatball preparation}

A beef round cut and other ingredients were purchased from a local market. Indonesian-style beef meatballs were manufactured according to a method described by Rohman, Erwanto, Man et al. (2011), with modifications in beef cube size and chopping time. First, excess fat and visible connective tissue in the beef were trimmed. Then, beef was cut into $4 \times 4 \mathrm{~cm}$ cubes and minced using a meat chopper for 1 min (MGB80, Ramesia Mesin Indonesia, Jakarta, Indonesia). Minced beef was divided into four groups and mixed with seaweed flour at different addition levels, salt, sugar, spices, tapioca, egg white and ice (Table 1). Each mixture from the four treatment groups was chopped for $2 \mathrm{~min}$. Three batches of each treatment were prepared. The batter was shaped into balls (approximately 11 g) and cooked in $70^{\circ} \mathrm{C}$-water and $96^{\circ} \mathrm{C}$-water for 5 min each (until the core temperature reached $72^{\circ} \mathrm{C}$ ). The core temperature of sampled meatballs was checked using a digital thermometer (DTH128, Shenzen Tonglixing Technology, Shenzen, China). The cooked meatballs were drained and then chilled at $4^{\circ} \mathrm{C}$ overnight prior to analysis. Meatballs were ground to determine prox- 
imate composition and $\mathrm{pH}$ using a food blender (HR7627, Philips Indonesia, Jakarta, Indonesia).

Table 1: Indonesian-style beef meatball formula

\begin{tabular}{lcccc}
\hline & \multicolumn{4}{c}{ Treatment $^{1}$} \\
\cline { 2 - 5 } Ingredient (g) & SF0 & SF2.5 & SF5 & SF7.5 \\
\hline Beef & 300 & 300 & 300 & 300 \\
Tapioca & 60 & 60 & 60 & 60 \\
Seaweed flour & 0 & 7.5 & 15 & 22.5 \\
Salt & 10.5 & 10.5 & 10.5 & 10.5 \\
Sugar & 10.5 & 10.5 & 10.5 & 10.5 \\
Pepper & 0.75 & 0.75 & 0.75 & 0.75 \\
Garlic & 7.5 & 7.5 & 7.5 & 7.5 \\
Egg white & 9.0 & 9.0 & 9.0 & 9.0 \\
Ice & 90 & 90 & 90 & 90 \\
\hline I Treatmo
\end{tabular}

1 Treatments: SF0, seaweed flour 0\%; SF2.5, seaweed flour $2.5 \%$; SF5, seaweed flour $5.0 \%$; SF7.5, seaweed flour 7.5\%. The addition level was weight per meat weight basis.

\subsection{Analysis methods}

\section{Proximate composition and $\mathrm{pH}$ determination}

Proximate composition; moisture, crude fat, crude protein, crude fiber and ash content were determined according to AOAC official methods (AOAC, 2005). Ground samples were dried in an oven at $105^{\circ} \mathrm{C}$ for $24 \mathrm{~h}$ to determine moisture content. Ether extraction was performed to analyze the crude fat content using the Soxhlet system. Nitrogen content was determined using the Kjeltec system (2200 Kjeltec Auto Distillation Unit, Foss, Hillerod, Denmark). Crude protein was then calculated as nitrogen content multiplied by 6.25 . Crude fiber was determined by acid hydrolysis with $1.25 \% \mathrm{H}_{2} \mathrm{SO}_{4}$ and followed by alkaline hydrolysis with $1.25 \% \mathrm{NaOH}$. Ash content was determined by burning the samples in a muffle furnace at $550^{\circ} \mathrm{C}$ for $8 \mathrm{~h}$.

For $\mathrm{pH}$ determination, the ground sample $(5 \mathrm{~g})$ was added to $10 \mathrm{~mL}$ distilled water and homogenized at $2500 \mathrm{rpm}$ for $2 \mathrm{~min}$. The $\mathrm{pH}$ of the slurry was then determined using a calibrated $\mathrm{pH}$ meter in duplicate (PHS-3DW, Shaoxing Worner Lab Equipment, Zhejiang, China).

\section{Physical characteristics}

Cooking loss was determined in triplicate based on the differences in weight of meatball samples before and after cooking at $80^{\circ} \mathrm{C}$ for $30 \mathrm{~min}$, and expressed as a percentage (\%). Water-holding capacity was measured in triplicate using the filter paper press method (Grau \& Hamm, 1953). A cooked sample was placed on filter paper and pressed at $35 \mathrm{~kg}$ for $5 \mathrm{~min}$. The area of water release was calculated, and the results were expressed as a percentage (\%). The hardness of the sample was measured using a Digital Force Gauge Imada ZP-200 N (Imada Co., Ltd., Aichi, Japan) according to the method of Utama, Jeong, Kim, Barido and Lee (2019) with modifications. The sample was compressed to $1 \mathrm{~cm}$ from the surface, with a test speed of $1.0 \mathrm{~mm} / \mathrm{s}$, using a 35-mm cylinder probe. The first peak was identified as hardness and expressed in Newton (N). The measurement of hardness was performed in triplicate. The instrumental surface color of the meatball was recorded at five random locations, in triplicate, based on the International Commission on Illumination's system for lightness (CIE $\left.\mathrm{L}^{*}\right)$, redness $\left(\mathrm{CIE} \mathrm{a}^{*}\right)$ and yellowness (CIE $\mathrm{b}^{*}$ ) using a CR-10 Plus color reader (Konica Minolta Inc., Tokyo, Japan). The light source of illuminant D65 (10 observer) with $8 \mathrm{~mm}$ aperture and attached-closed cone was calibrated using a white plate $(\mathrm{Y}=93.6, \mathrm{X}=0.3134, \mathrm{y}=0.3194)$.

\section{Sensory evaluation}

A total of 5 trained panelists were asked to evaluate the samples. Panelists were faculty members who had been trained for three sessions using commercial Indonesian-style beef meatballs. This study was approved by the research ethics committee (REC) of Universitas Brawijaya. Drinking water to clean the palate and remove residual flavors was provided. Samples were reheated using a microwave for $1 \mathrm{~min}$, put on white dishes which were individually labeled with 3-digit random numbers, and served to panelists in random order. Three sessions were per- 
SI114 $\mid$ Widati et al.

formed using two samples per session. Color, texture, aroma, taste and overall acceptance of the samples were assessed. The 5-scales adapted from Watts, Ylimaki, Jeffery and Elias (1989) were used for sensory evaluation. Color: 1 (dark brown and dark grey), 2 (dark brown and grey), 3 (brown and grey), 4 (light brown and grey), 5 (light brown and light grey). Texture: 1 (mushy), 2 (moderately mushy), 3 (moderately chewy), 4 (chewy), 5 (very chewy). Aroma: 1 (very dominant seaweed aroma), 2 (dominant seaweed aroma), 3 (balance seaweed and meat aroma), 4 (dominant meat aroma), 5 (very dominant meat aroma). Taste: 1 (very dominant seaweed taste), 2 (dominant seaweed taste), 3 (balance seaweed and meat taste), 4 (dominant meat taste), 5 (very dominant meat taste).

\section{Microstructure}

A scanning electron microscope (SEM, TM3000, Hitachi High-Technologies Corp., Tokyo, Japan) was used to observe the microstructure of the Indonesian-style beef meatballs. The method was adapted from Hashemi and Jafarpour (2016). A 1-2 mm thick slice of each sample was fixed with $2.5 \%$ glutaraldehyde in $0.2 \mathrm{M}$ phosphate buffer ( $\mathrm{pH} 7.0$ ) for $2 \mathrm{~h}$, washed and soaked in distilled water for $1 \mathrm{~h}$, and serial dehydrated with ethanol in distilled water $(50 \%$, $60 \%, 70 \%, 80 \%, 90 \%$ and $100 \%, \mathrm{v} / \mathrm{v})$ for $1 \mathrm{~h}$. The dried sample was put onto a holder, coated with gold and visualized under SEM at a magnification of $\times 2000$.

\section{$2.4 \quad$ Statistical analysis}

This study to determine the effect of addition level of seaweed employed a completely randomized design. There were four seaweed addition levels $(0 \%, 2.5 \%, 5.0 \%$ and $7.5 \%)$ and three replications. One-way analysis of variance (ANOVA) was employed to determine the effect of addition level of seaweed. Significant differences (P $<0.05)$ of mean values among treatments were determined using Duncan's multiple range test.

\section{Results and Discussion}

\subsection{Proximate composition}

The addition of seaweed (Eucheuma cottonii) flour affected the proximate composition of the Indonesian-style beef meatball significantly (Table 2). The fat, protein and ash contents of the cooked Indonesian-style beef meatball with added seaweed flour were $<=2.0 \%,>=9.0 \%$ and $<=3.0 \%$, respectively, in accordance with the national standard (Badan Standardisasi Nasional, 1995). However, the moisture content did not comply with the standard as it was greater than $70 \%$. An increasing level of seaweed flour added to meatballs reduced the moisture content $(\mathrm{P}<0.01)$ as the flour increased the proportion of dry matter. The moisture content of seaweed flour itself was $13.83 \%$. The moisture content of the Indonesian-style beef meatball was over the standard of $70 \%$ because ice used in this study was $30 \%$ of the meat weight and the beef was extremely lean with fat, protein and moisture contents of $4.23 \%, 18.70 \%$ and $74.5 \%$, respectively. The use of lean beef and the addition of seaweed flour also reduced protein $(\mathrm{P}<0.05)$ and fat $(\mathrm{P}$ $<0.01)$ content of the cooked Indonesian-style beef meatball.

The presence of fiber in seaweed flour contributed positively $(\mathrm{P}<0.01)$ to the crude fiber and ash content of the cooked Indonesian-style beef meatball. The crude fiber and ash content of the seaweed flour used in this study were $16.52 \%$ and $11.46 \%$, respectively. Therefore, seaweed flour added fiber and dry matter to the meatballs. Hartati and Endang (2011) reported that the unprocessed Eucheuma cottonii contains $26.83 \%$ moisture, $0.46 \%$ fat, $2.75 \%$ protein, $5.07 \%$ crude fiber and $17.86 \%$ ash. After ovendrying at $90-100^{\circ} \mathrm{C}$ for $12 \mathrm{~h}$ and milling, the Eucheuma cottonii flour comprised $87.99 \%$ dry matter of which $38.77 \%$ was water-soluble dietary fiber and $43.17 \%$ was insoluble dietary fiber (Wresdiyati, Hartanta \& Astawan, 2008).

\subsection{Physical characteristics}

The addition of seaweed (Eucheuma cottonii) flour affected physical characteristics of the 
Seaweed flour-added Indonesian-style beef meatball $\mid$ SI115

Table 2: Proximate composition of an Indonesian-style beef meatball made with different addition levels of seaweed (Eucheuma cottonii) flour

\begin{tabular}{|c|c|c|c|c|c|}
\hline \multirow{2}{*}{ Variable } & \multicolumn{4}{|c|}{ Treatment $^{1}$} & \multirow{2}{*}{$\begin{array}{c}\text { Significance } \\
\text { level }^{2}\end{array}$} \\
\hline & SF0 & SF2.5 & SF5 & SF7.5 & \\
\hline Moisture (\%) & $72.22^{c} \pm 0.20$ & $72.15^{b c} \pm 0.38$ & $71.37^{a b} \pm 0.29$ & $71.25^{a} \pm 0.18$ & $* *$ \\
\hline Crude fat $(\%)$ & $0.27^{b} \pm 0.04$ & $0.12^{a} \pm 0.03$ & $0.08^{a} \pm 0.01$ & $0.07^{a} \pm 0.01$ & $* *$ \\
\hline Crude protein (\%) & $12.00^{b} \pm 1.11$ & $9.67^{a} \pm 1.12$ & $9.90^{a} \pm 0.50$ & $10.31^{a} \pm 0.15$ & $*$ \\
\hline Crude fiber (\%) & $0.21^{a} \pm 0.02$ & $0.33^{b} \pm 0.03$ & $0.45^{c} \pm 0.01$ & $0.58^{d} \pm 0.05$ & $* *$ \\
\hline Ash & $0.44^{a} \pm 0.01$ & $0.62^{a b} \pm 0.07$ & $0.80^{b c} \pm 0.18$ & $0.94^{c} \pm 0.05$ & $* *$ \\
\hline
\end{tabular}

Data are presented as mean \pm standard deviation $(\mathrm{n}=3) .{ }^{1}$ Treatments: SF0, seaweed flour 0\%; SF2.5, seaweed flour 2.5\%; SF5, seaweed flour 5.0\%; SF7.5, seaweed flour 7.5\%. The addition level was weight per meat weight basis. ${ }^{2}$ Significance level: ${ }^{*} \mathrm{P}<0.05$; $* * \mathrm{P}<0.01$.

Table 3: Physical characteristics of an Indonesian-style beef meatball made with different addition levels of seaweed (Eucheuma cottonii) flour

\begin{tabular}{|c|c|c|c|c|c|}
\hline \multirow[b]{2}{*}{ Variable } & \multicolumn{4}{|c|}{ Treatment $^{1}$} & \multirow{2}{*}{$\begin{array}{c}\text { Significance } \\
\text { level }^{2}\end{array}$} \\
\hline & SF0 & SF2.5 & SF5 & SF7.5 & \\
\hline $\mathrm{pH}$ & $5.94^{a} \pm 0.10$ & $6.00^{a b c} \pm 0.03$ & $6.03^{b c} \pm 0.08$ & $6.07^{c} \pm 0.05$ & $*$ \\
\hline Cooking loss (\%) & $1.67^{c} \pm 0.19$ & $1.36^{b c} \pm 0.20$ & $0.99^{a b} \pm 0.03$ & $0.74^{a} \pm 0.08$ & $* *$ \\
\hline Water-holding capacity (\%) & $50.67^{a} \pm 5.41$ & $59.63^{a b c} \pm 3.71$ & $63.80^{b c} \pm 1.20$ & $64.11^{c} \pm 3.23$ & $* *$ \\
\hline Hardness $(\mathrm{N})$ & $12.00^{a} \pm 0.43$ & $13.83^{a} \pm 0.20$ & $16.83^{b} \pm 1.20$ & $20.83^{c} \pm 1.34$ & $* *$ \\
\hline CIE L* & $48.30^{b} \pm 1.32$ & $46.83^{a b} \pm 1.24$ & $44.63^{a} \pm 0.49$ & $43.93^{a} \pm 1.16$ & $* *$ \\
\hline CIE a* & $20.07^{c} \pm 0.67$ & $19.10^{b c} \pm 0.52$ & $17.47^{a b} \pm 0.90$ & $16.60^{a} \pm 2.04$ & $*$ \\
\hline CIE b* & $16.00^{b} \pm 0.65$ & $14.93^{a b} \pm 0.11$ & $14.00^{a} \pm 0.61$ & $13.53^{a} \pm 0.66$ & $* *$ \\
\hline
\end{tabular}

Data are presented as mean \pm standard deviation $(\mathrm{n}=3) .{ }^{1}$ Treatments: SF0, seaweed flour 0\%; SF2.5,

seaweed flour 2.5\%; SF5, seaweed flour 5.0\%; SF7.5, seaweed flour 7.5\%. The addition level was

weight per meat weight basis. ${ }^{2}$ Significance level: ${ }^{*} \mathrm{P}<0.05 ; * * \mathrm{P}<0.01$.

Indonesian-style beef meatball (Table 3). The $\mathrm{pH}$ and water-holding capacity of the cooked Indonesian-style beef meatball were enhanced by addition of seaweed flour. In contrast, cooking loss, $\mathrm{L}^{*}$ value (lightness), $\mathrm{a}^{*}$ (redness) and $\mathrm{b}^{*}$ (yellowness) declined as the addition level of seaweed flour was increased.

The $\mathrm{pH}$ of the control meatballs was lower than normal Indonesian-style beef meatballs (6.056.07) according to Purnomo (2012), as the beef used in this study was purchased after 24-h postmortem with a $\mathrm{pH}$ of $5.64 \pm 0.10$. In general, an Indonesian-style meatball is made from early postmortem beef but the quality is comparable with that made from late postmortem beef (Purnomo \& Rahardiyan, 2008). The pH of prerigor beef is usually above 5.90 (Utama et al., 2017). However, the $\mathrm{pH}$ of the Indonesianstyle beef meatball with added seaweed flour was higher than that of the control. The $\mathrm{pH}$ increasing effect of seaweed flour was caused by the presence of alkaline minerals such as sodium, potassium, calcium and magnesium (Fitri, 2012). The $\mathrm{pH}$ of the seaweed flour used in this study was $7.89 \pm 0.59$.

Seaweed flour improved texture, particularly hardness, and water-holding capacity of the Indonesian-style beef meatball resulting in an enhanced cooking yield. These were caused by k-carrageenan in Eucheuma cottonii that possesses good water-binding properties and thus strengthens the gel matrix in heat-induced meat 
SI116 $\mid$ Widati et al.

Table 4: Sensory characteristics of an Indonesian-style beef meatball made with different addition levels of seaweed (Eucheuma cottonii) flour

\begin{tabular}{lccccc}
\hline \multirow{2}{*}{ Variable } & \multicolumn{3}{c}{ Treatment $^{1}$} & \multicolumn{2}{c}{ Significance } \\
\cline { 2 - 5 } & SF0 & SF2.5 & SF5 & SF7.5 & level $^{2}$ \\
\hline Color & $4.44^{c} \pm 0.51$ & $4.22^{b c} \pm 0.55$ & $3.89^{a b} \pm 0.90$ & $3.56^{a} \pm 1.15$ & $* *$ \\
Texture & $3.11^{a} \pm 1.28$ & $3.61^{a b} \pm 1.04$ & $4.17^{b c} \pm 0.71$ & $4.33^{c} \pm 0.84$ & $* *$ \\
Aroma & $3.61^{c} \pm 0.98$ & $3.17^{b c} \pm 0.62$ & $2.67^{a b} \pm 0.85$ & $2.28^{a} \pm 0.96$ & $* *$ \\
Taste & $4.11^{c} \pm 0.83$ & $3.67^{b c} \pm 0.77$ & $2.72^{a} \pm 0.83$ & $2.11^{a} \pm 1.13$ & $* *$ \\
\hline
\end{tabular}

Data are presented as mean \pm standard deviation $(n=3)$.

Color: 1 (dark brown and dark grey), 2 (dark brown and grey), 3 (brown and grey),

4 (light brown and grey), 5 (light brown and light grey).

Texture: 1 (mushy), 2 (moderately mushy), 3 (moderately chewy), 4 (chewy),

5 (very chewy)

Aroma: 1 (very dominant seaweed aroma), 2 (dominant seaweed aroma), 3 (balanced seaweed and meat aroma), 4 (dominant meat aroma), 5 (very dominant meat aroma).

Taste: 1 (very dominant seaweed taste), 2 (dominant seaweed taste), 3 (balanced seaweed and meat taste), 4 (dominant meat taste), 5 (very dominant meat taste).

1 Treatments: SF0, seaweed flour 0\%; SF2.5, seaweed flour 2.5\%; SF5, seaweed flour

$5.0 \%$; SF7.5, seaweed flour 7.5\%. The addition level was weight per meat weight basis.

2 Significance level: ${ }^{* *} \mathrm{P}<0.01$.

emulsion products and increases cooking yield (Purnomo, 2012). DeFreitas, Sebranek, Olson and Carr (1997) mentioned that k-carrageenan has one ester sulfate and one negative charge between sulfate chains, thus enhancing waterbinding properties of the meat batter. Micrographs of the Indonesian-style beef meatball (Fig. 1) show that i) seaweed (Eucheuma cottonii) flour could interact with beef protein, tapioca and water to build a compact gel matrix and ii) the increasing level of addition reduced the amount and size of the pores. The pore size found in the control group was larger than that of treatment groups. A previous study also reported that k-carrageenan in Eucheuma cottonii improved gel strength and water-holding capacity of catfish sausage (Yakhin et al., 2015). Carrageenan could also be used as a fat replacer in emulsion-type meat products to reduce cooking loss and improve texture (Cierach, ModzelewskaKapitula \& Szacilo, 2009). Eucheuma cottonii as a source of dietary fiber could be used to add fiber in processed food (Kurniawan et al., 2012). The capillary-like structure of dietary fiber has a function to absorb water thus it could be added to emulsion-type meat products to improve yield and texture, and also offer nutritional benefits (Talukder, 2015).

The decrease in color variables caused by the addition of seaweed (Eucheuma cottonii) flour resulted in a darker appearance of the Indonesianstyle beef meatball. The brown appearance of the meatball is the result of globin hemochromogen denaturation during thermal processing (Pearson \& Gillett, 2012). In addition, the color of seaweed flour used in this study was light brown. Therefore, the $\mathrm{L}^{*}, \mathrm{a}^{*}$ and $\mathrm{b}^{*}$ values of the treatment groups were lower than those of the control and the effect was level dependent. Veronika, Mappiratu and Sumarni (2017) reported that the pigment extracted from Eucheuma cottonii was light brown. The use of Eucheuma cottonii flour at more than $1 \%$ in a fish meatball also resulted in a darker appearance (Manuel et al., 2015).

\subsection{Sensory characteristics}

The addition of seaweed (Eucheuma cottonii) flour affected $(\mathrm{P}<0.01)$ the sensory characterist- 
Seaweed flour-added Indonesian-style beef meatball |SI117
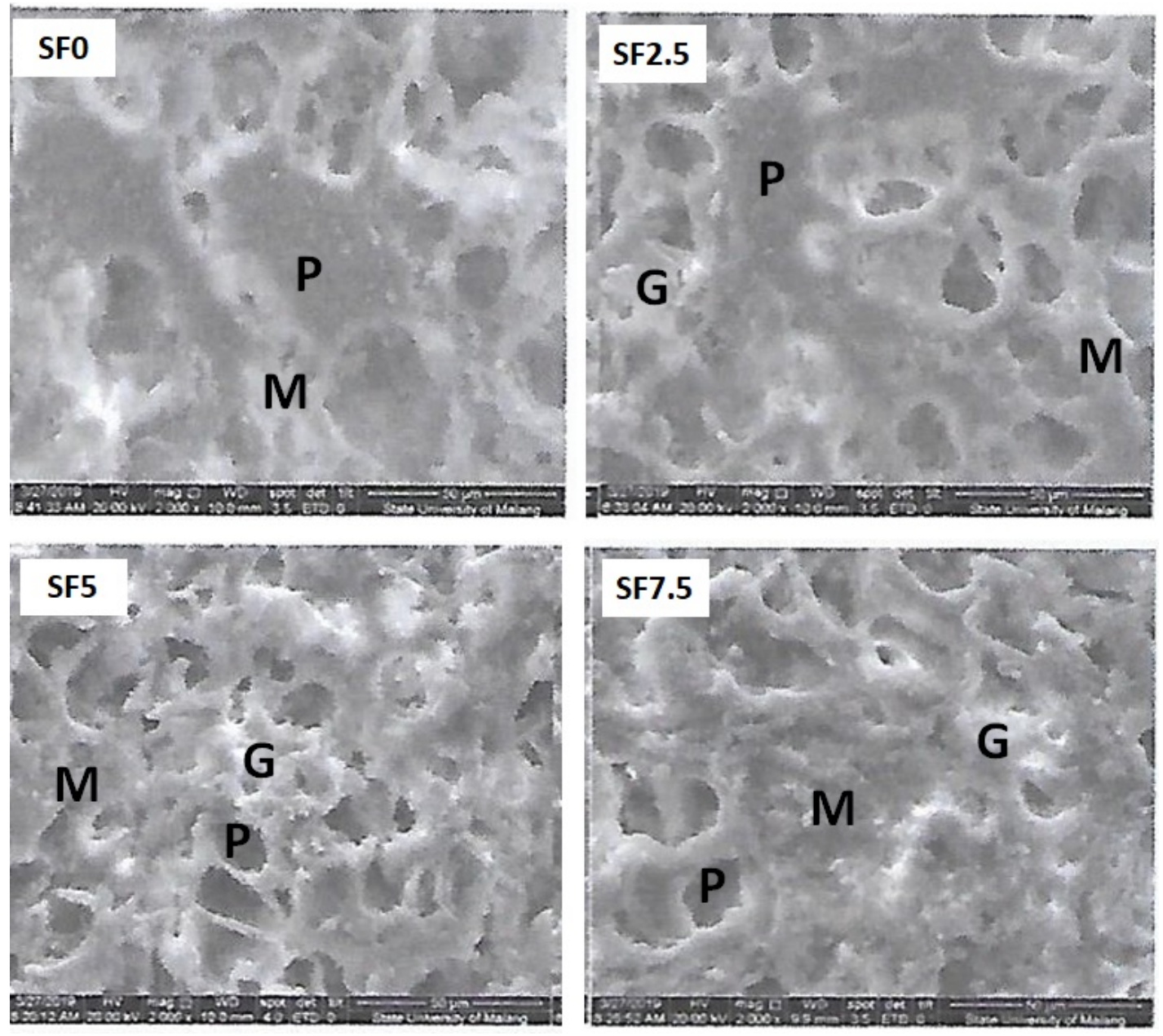

Figure 1: Microstructure of an Indonesian-style beef meatball with added seaweed flour. SF0 (seaweed flour 0\%), SF2.5 (seaweed flour 2.5\%), SF5 (seaweed flour 5.0\%), and SF7.5 (seaweed flour 7.5\%). G= seaweed flour granule, $\mathrm{M}=$ matrix, and $\mathrm{P}=$ pore. 
SI118 | Widati et al.

ics of the Indonesian-style beef meatball (Table 4). Trained panelists revealed that higher addition levels of seaweed flour resulted in darker meatballs. The normal and acceptable color of an Indonesian style-meatball should combine light brown and light grey with a pink note (Badan Standardisasi Nasional, 2014). In this study, the color of the Indonesian-style beef meatball ranged from 3.56 (brown and grey) to 4.44 (light brown and grey). Among treatments, the color of the SF2.5 group was comparable with that of the control. Seaweed flour increased chewiness and the dominancy of seaweed aroma and taste. Pramuditya and Yuwono (2014) reported that the most favorable Indonesian-style beef meatball has a chewy texture and is not mushy. Cierach et al. (2009) mentioned that kcarrageenan (10\% addition level) improves the texture and color of frankfurters. In this study, panelists noted that the seaweed aroma was more dominant in samples with more than $2.5 \%$ SF. A previous study reported that the addition level of Eucheuma cottonii up to $1.0 \%$ (the maximum level used in the study) did not affect the sensory characteristics including color, aroma and taste of catfish meatballs (Yakhin et al., 2015). Among treatments, the sensory characteristics of the SF2.5 group were comparable with those of the control. These results suggest that seaweed flour could be added at $2.5 \%$ of meat weight to produce Indonesian style-beef meatballs with sensory characteristics comparable to original ones and enhanced fiber content.

\section{Conclusion}

Seaweed (Eucheuma cottonii) flour addition increased hardness, water-holding capacity and fiber content of an Indonesian-style beef meatball. It also increased the seaweed aroma when added at more than $2.5 \%$. Therefore, the addition of seaweed flour at $2.5 \%$ of meat weight could be applied to produce Indonesian-style beef meatballs with enhanced fiber content and sensory properties comparable to the original ones.

\section{Acknowledgements}

The authors would like to thank the Directorate General of Higher Education of the Republic of Indonesia (DIKTI) for Beasiswa Pendidikan Pascasarjana and the Faculty of Animal Science, Universitas Brawijaya for financial support.

\section{References}

AOAC. (2005). Official Methods of Analysis. 18th ed, Gathersburg (MD): Association of Official Analytical Chemists International (AOAC).

Badan Standardisasi Nasional. (1995). SNI Bakso Daging. SNI 01-3818-1995. Badan Standardisasi Nasional, Jakarta.

Badan Standardisasi Nasional. (2014). Standar Nasional Indonesia-Bakso Daging. SNI 3818. Badan Standardisasi Nasional, Jakarta.

Campo, V. L., Kawano, D. F., da Silva, D. B., Jr. \& Carvalho, I. (2009). Carrageenans: Biological properties, chemical modifications and structural analysis-a review. Carbohydrate Polymers, 77(2), 167-180. doi:10. 1016/j.carbpol.2009.01.020

Cierach, M., Modzelewska-Kapitula, M. \& Szacilo, K. (2009). The influence of carrageenan on the properties of low-fat frankfurters. Meat Science, 82(3), 295-299. doi:10.1016/j.meatsci.2009.01.025

DeFreitas, Z., Sebranek, J. G., Olson, D. G. \& Carr, J. M. (1997). Carrageenan effects on thermal stability of meat proteins. Journal of Food Science, 62(3), 544-547. doi:10. 1111/j.1365-2621.1997.tb04426.x

Fitri, M. (2012). Kajian sifat fisiko-kimia karaginan dari rumput laut jenis eucheuma sp. di perairan sulawesi selatan. Jurnal Galung Tropika, 2(2).

Grau, R. \& Hamm, R. (1953). Eine einfache methode zur bestimmung der wasserbindung im muskel. Naturwissenschaften, 40(1), 29-30.

Guerrero, S. N., Campos, C. A. \& Alzamora, S. M. (2002). Development of shelf stable seaweed by hurdle processing. Food Science 
and Technology International, 8(2), 95-99. doi:10.1106/108201302024588

Hartati, H. \& Endang, M. (2011). Effect of Euchema cottonii seaweed as the natural gelling agent for quality beef meatball. Berita Litbang Industri: Media Publikasi dan Komunikasi Peneliti Industri, 2(47), 5465. Retrieved from https://lib.atmajaya. ac . id / default . aspx ? tabID $=61 \& \mathrm{id}=$ 240579\&src $=\mathrm{a}$

Hashemi, A. \& Jafarpour, A. (2016). Rheological and microstructural properties of beef sausage batter formulated with fish fillet mince. Journal of Food Science and Technology-mysore, 53(1), 601-610. doi:10. 1007/s13197-015-2052-4

Kurniawan, A. B., Al-Baarri, A. N. \& Kusrahayu, K. (2012). Kadar serat kasar, daya ikat air, dan rendemen bakso ayam dengan penambahan karaginan. Jurnal Aplikasi Teknologi Pangan, 1(2).

Lee, B. J., Hendricks, D. G. \& Cornforth, D. P. (1998). Effect of sodium phytate, sodium pyrophosphate and sodium tripolyphosphate on physico-chemical characteristics of restructured beef. Meat Science, 50(3), 273-283. doi:10 . 1016 / S0309 - 1740(98) 00002-3

MacArtain, P., Gill, C. I. R., Brooks, M., Campbell, R. \& Rowland, I. R. (2007). Nutritional value of edible seaweeds. Nutrition Reviews, 65(12, 1), 535-543. doi:10.1301/ nr.2007.dec.535-543

Manuel, J., Cornelia, M. \& Wijaya, W. (2015). Utilization of eucheuma cottonii and eucheuma spinosum flour in narrow-barred spanish mackerel meatballs. In R. Setyobudi, J. Burlakovs, M. Mel, P. Adinurani \& Z. VincevicaGaile (Eds.), International symposium on aquatic product processing (isapprosh) 2013 (Vol. 1, pp. 12-18). KnE Life Sciences. 1st International Symposium on Aquatic Product Processing, Safety and Health (ISAPPROSH), Bogor, INDONESIA, NOV 13-14, 2013. doi:10.18502/kls . v1i0.78

Pearson, A. M. \& Gillett, T. A. (2012). Processed meats. Springer.

Pramuditya, G. \& Yuwono, S. S. (2014). Penentuan atribut mutu tekstur bakso sebagai syarat tambahan dalam sni dan pengaruh lama pemanasan terhadap tekstur bakso [in press oktober 2014]. Jurnal Pangan dan Agroindustri, 2(4), 200-209.

Purnomo, H. \& Rahardiyan, D. (2008). Review article: Indonesian traditional meatball. International Food Research Journal, 15(2), 101-108.

Purnomo, H. (2012). Teknologi pengolahan dan pengawetan daging. Universitas Brawijaya Press.

Rifqie Mariana, R., Hidayati, L. \& Soekopitojo, S. (2019). Implementing the haccp system to the production of bakso malangindonesia. Journal of Culinary Science $\&$ Technology, 17(4), 291-312.

Rohman, A., Erwanto, Y., Man, Y. B. C. et al. (2011). Analysis of pork adulteration in beef meatball using fourier transform infrared (ftir) spectroscopy. Meat Science, $88(1), 91-95$.

Talukder, S. (2015). Effect of dietary fiber on properties and acceptance of meat products: A review. Critical Reviews in Food Science and Nutrition, 55(7), 10051011. doi:10.1080/10408398.2012.682230

Tan, M. G. (2002). Chinese dietary culture in indonesian urban society. The globalization of Chinese food, 152(1997), 33-65.

Utama, D. T., Jeong, H. S., Kim, J., Barido, F. H. \& Lee, S. K. (2019). Fatty acid composition and quality properties of chicken sausage formulated with preemulsified perilla-canola oil as an animal fat replacer. Poultry Science, 98(7), 30593066. doi:10.3382/ps/pez105

Utama, D. T., Lee, S. G., Baek, K. H., Chung, W. S., Chung, I. A., Jeon, J. T. \& Lee, S. K. (2017). High pressure processing for darkfirm-dry beef: Effect on physical properties and oxidative deterioration during refrigerated storage. Asian-australasian Journal of Animal Sciences, 30(3), 424-431. doi:10 . 5713 /ajas. 16.0175

Veronika, H. H., Mappiratu, M. \& Sumarni, N. K. (2017). Ekstraksi dan karakterisasi ekstrak zat warna rumput laut (eucheuma cottonii). KOVALEN: Jurnal Riset Kimia, 3(1), 7-16. 
Watts, B. M., Ylimaki, G. L., Jeffery, L. E. \& Elias, L. G. (1989). Basic sensory methods for food evaluation. IDRC, Ottawa, ON, CA.

Wresdiyati, T., Hartanta, A. B. \& Astawan, M. (2008). The effect of seaweed eucheuma cottonii on superoxide dismutase (sod) liver of hypercholesterolemic rats. HAYATI Journal of Biosciences, 15(3), 105-110.

Yakhin, L. A., Wijaya, K. M. \& Santoso, J. (2015). The effect of seaweed powder (eucheuma cottonii) addition in catfish sausage. In R. Setyobudi, J. Burlakovs, M. Mel, P. Adinurani \& Z. VincevicaGaile (Eds.), International symposium on aquatic product processing (isapprosh) 2013 (Vol. 1, pp. 1-5). KnE Life Sciences. 1st International Symposium on Aquatic Product Processing, Safety and Health (ISAPPROSH), Bogor, INDONESIA, NOV 13-14, 2013. doi:10.18502/kls.v1i0.76 